\title{
Morfologi dan Citra Kota Kawasan Kauman, Kecamatan Juwana, Kabupaten Pati
}

\section{The Morphology and Image of Kauman Town, Juwana Sub District, Pati Regency}

\author{
Wildansyah Firdaus Adiguna') a)*, Marisa Triyanti2) b) \\ 1) Dinas Pekerjaan Umum dan Penataan Ruang Kabupaten Pati \\ a) Jl. P. Sudirman No. 66 Pati, 59114. Jawa Tengah \\ 2) Kantor Pertanahan Kota Pagar Alam \\ b) Jl. Laskar Wanita Mentarjo Pagar Alam, 31581. Sumatera Selatan \\ *Email: wildansyahfirdausadiguna@gmail.com
}

Naskah Masuk: 8 Desember $2020 \quad$ Naskah Revisi: 15 April $2021 \quad$ Naskah Diterima: 27 April 2021

\begin{abstract}
Physical elements to form city image that can be perceived through the function, location, and character of a certain urban area, are the keys to obtain the image of city. Kauman is a developing urban area in Juwana Sub-district, Pati Regency. This research aims to identify the elements of urban morphology and the forming elements of the city image in Kauman through the mental map method, based on the perceptions, experiences, memories, and feelings of its community. This study uses a qualitative method with a descriptive analysis approach. This study used Trancik's theory to investigate urban morphology and used Lynch's theory to identify the forming elements of the city image. The urban morphology of Kauman was arranged as follows: solid elements were found in figure-ground, 1 point single block, and 2 groups at Jalan W.R. Supratman as multiple blocks. Meanwhile, void elements found 2 points. Linkage elements found a point. There are 3 styles of architecture still founded in Kauman, including Colonial, Javanese traditional, and Chinese style. Based on the analysis of the physical elements forming the Kauman Juwana image, it is arranged through 13 objects, there are 2 path elements, 4 edge elements, 3 district elements, 1 node element, and 3 landmark elements.
\end{abstract}

Keywords: Juwana, physical elements, town image, urban morphology

\begin{abstract}
ABSTRAK
Elemen fisik pembentuk citra kota yang dapat dirasakan melalui fungsi, lokasi, dan karakter merupakan kunci untuk mengetahui gambaran citra kota tersebut. Kauman merupakan kawasan perkotaan di Kecamatan Juwana, Kabupaten Pati yang terus mengalami perkembangan berikut citranya. Penelitian ini bertujuan untuk mengidentifikasi elemen morfologi kota dan elemen pembentuk citra kota di Kauman melalui metode peta mental berdasarkan persepsi, pengalaman, ingatan, dan perasaan masyarakat Kauman. Penelitian menggunakan metode kualitatif dengan analisis deskriptif. Penelitian ini mengkaji elemen morfologi kota berdasarkan teori Trancik dan elemen pembentuk citra kota berdasarkan teori Lynch. Hasil penelitian menunjukkan bahwa morfologi Kota Kauman disusun melalui objek sebagai berikut elemen solid ditemukan pada figure ground, blok tunggal 1 titik, dan blok ganda ditemukan 2 kelompok di koridor Jalan W. R. Supratman, sedangkan elemen void ditemukan 2 elemen; linkage ditemukan 3 elemen; dan place ditemukan 1 titik. Penampakan bangunan berkarakter kuat yang mewakili suatu langgam atau gaya bangunan tertentu yang ditemukan yaitu bangunan bergaya Kolonial, Tradisional Jawa, dan Cina. Berdasarkan analisis, elemen fisik pembentuk citra Kauman Juwana disusun melalui 13 objek, meliputi 2 elemen jalur (path), 4 elemen batas (edge), 3 elemen kawasan (district), 1 elemen titik temu (nodes), dan 3 elemen penanda kawasan (landmark).
\end{abstract}

Kata kunci : Juwana, elemen fisik, citra kota, morfologi kota

\section{PENDAHULUAN}

Tumbuh kembang suatu kota dipengaruhi oleh dinamika yang terjadi pada penduduk dan segala aspek yang berkaitan dengan mereka. Dampaknya akan terlihat pada perkembangan aktivitas dan perkembangan kawasan terbangun. Kehidupan sosial budaya, politik, dan ekonomi yang diwadahi dalam kota tersebut akan mendorong penyesuaian dalam pemenuhan kebutuhan ruang bagi aktivitas masyarakat. Sebuah kota tergambarkan melalui lingkungan dan elemen-elemennya. Menurut Lynch (1960), elemen-elemen pembentuk citra kota terdiri dari paths (jalan), edges (batas), districs (kawasan), nodes (simpul), dan 
landmark (tetenger). Melalui citra tersebut, makna bentuk kota bagi masyarakat yang mendiaminya akan lebih mudah diketahui, sekaligus menjelaskan pentingnya persepsi masyarakat terkait. Citra kota, dimana elemen-elemen pembentuknya berdasarkan fisik kawasan akan terpengaruh oleh perkembangan kawasan terbangun. Selain itu, terdapat pendapat yang menyatakan bahwa budaya memengaruhi pembentukan citra suatu kota (Tallo, Pratiwi, \& Astutik, 2014). Hal tersebut juga berlaku untuk aktivitas sosial dan perekonomian lokal. Terdapat keterkaitan yang bersifat timbal balik dalam hubungan antara citra kota, aktivitas masyarakat, dan keadaan fisik kawasan. Setiap elemen akan saling memengaruhi dan membentuk gambaran identitas suatu kota.

Perkembangan kota-kota di Jawa, khususnya pesisir pantai utara Pulau Jawa, dipengaruhi oleh aktivitas perdagangan yang mengandalkan perairan. Interaksi dagang yang terjadi antarpelaku yang merupakan penduduk lokal maupun asing memicu munculnya akulturasi budaya. Salah satunya dapat dijumpai di sebuah kota kecil di pesisir pantai utara Jawa, yaitu Juwana. Juwana berada dalam wilayah Kabupaten Pati. Juwana bernilai strategis dengan posisinya yang dilewati oleh jalan nasional yang cukup ramai. Penduduk Juwana mayoritas merupakan masyarakat suku Jawa dan terdapat penduduk keturunan Tionghoa dalam jumlah yang sedikit. Selain keberagaman suku, terdapat pula ragam gaya bangunan di Juwana, tepatnya di Desa Kauman. Selain bangunan dengan karakter arsitektur Jawa dan Cina, terdapat bangunan dengan gaya kolonial. Karakter kolonial pada bangunan adalah wujud peninggalan masa kolonial Belanda karena pada masa tersebut, Juwana berstatus daerah keasisten-residenan. Secara umum, Desa Kauman terdiri dari Kampung Kauman dan Kampung Pecinan. Kampung Kauman mewakili kawasan dengan karakter Islam dan Jawa dengan bangunan penanda adalah Masjid Agung Juwana. Sementara itu, Kampung Pecinan mewakili karakter Cina dengan bangunan penanda berupa kelenteng.

Kauman memiliki fungsi sebagai tempat bermukim bagi masyarakat setempat. Selain itu, Kauman juga menjadi salah satu simpul perekonomian di Kecamatan Juwana bahkan Kabupaten Pati. Perkembangan kota yang pesat dan peran sebagai simpul perekonomian serta perdagangan, Kauman menghadapi ancaman perubahan menyebabkan fisik bangunan yang memiliki karakteristik tertentu. Perubahan lanskap tersebut juga dapat berkontribusi terhadap perubahan lingkungan fisik kota (Wulanningrum, 2016).

Pertumbuhan fisik di Juwana cenderung kurang dapat dikendalikan. Kawasan lama, khususnya Kampung Pecinan terlihat terbengkalai. Kawasan tersebut mulai ditinggalkan, padahal bangunan-bangunan yang ada di kawasan tersebut merupakan pembentuk kawasan yang perlu dilestarikan untuk memberi makna dan citra kawasan (Lake, Mberu, \& Diaz, 2019).

Elemen pembentuk kota menjadi hal yang menarik untuk dipelajari, utamanya perubahan perkembangan kawasan warisan budaya. Kawasan tersebut biasanya ditandai dengan keberadaan bangunan bernilai sejarah. Pelestarian elemen pembentuk kota perlu dilakukan sehingga dapat mendukung citra dan fungsi dari suatu kawasan (Lake, et al., 2019)

Penelitian ini bertujuan untuk: 1)mengidentifikasi elemen morfologi kota dan elemen pembentuk citra kota di kawasan Kauman melalui metode peta mental berdasarkan persepsi, pengalaman, ingatan, dan perasaan masyarakat Kauman; 2) menganalisis bentuk kota secara tekstural dengan menginterpretasikan bentuk kota, baik dalam dua dimensi maupun tiga dimensi.

Penelitian mengenai elemen-elemen pembentuk citra kota di Kauman ini diharapkan dapat bermanfaat bagi perencana kota dan pihak terkait dalam membangun citra yang lebih jelas. Diharapkan fokus pembangunan Kawasan Kauman tidak merusak potensi yang telah ada, sekaligus menempatkan pendapat mayoritas penduduk kawasan sebagai tolak ukur kualitas fisik kawasan. Penelitian ini juga dapat digunakan sebagai dasar atau alat bantu untuk memahami permasalahan dan potensi peluang. Selain itu, hasil penelitian juga dapat dipertimbangkan sebagai alternatif solusi untuk mengatasi permasalahan dalam rangka merancang Kauman di masa mendatang. 


\section{TINJAUAN PUSTAKA}

\section{Sejarah Perkembangan Kota Pesisir}

Perkembangan kota pesisir memiliki keeratan hubungan dengan awal pembangunan ekonomi dan kemakmuran suatu wilayah (Kurniati, 2016). Kota-kota di Indonesia banyak tumbuh dimulai dari wilayah pesisir. Hal ini tidak terlepas dari karakteristik Indonesia sebagai negara kepulauan. Berdasarkan sejarah nusantara, perkembangan pusat-pusat kerajaan di nusantara banyak berpusat di wilayah pesisir atau berhubungan dengan sistem sungai pada kerajaan yang terletak di pedalaman. Kapal-kapal pedagang asing sering singgah di nusantara untuk melakukan kegiatan perdagangan. Pedagang yang memiliki tujuan berdagang tersebut berasal dari wilayah Jazirah Arab, Gujarat, maupun Daratan Tiongkok. Oleh karena itu, ditemukan situssitus peninggalan berupa permukiman etnis yang berdampingan atau bahkan berakulturasi maupun berasimilasi dengan penduduk setempat. Baiquni dalam Kurniati (2016) menjelaskan bahwa pada abad VII hingga abad XVII, kerajaan-kerajaan berbasis maritim muncul silih berganti, seperti Samudera Pasai, Sriwijaya, Kesultanan Demak, Kesultanan Ternate, dan Kesultanan Banten. Kerajaan-kerajaan maritim tersebut mencapai masa keemasan dengan mengembangkan perdagangan, baik di nusantara hingga mancanegara.

Perkembangan kota-kota di Jawa banyak dipengaruhi oleh aktivitas perdagangan dari luar. Oleh karena itu, kota-kota pada umumnya berkembang di pesisir pantai utara Pulau Jawa. Interaksi yang terjadi melalui perdagangan di daerah pesisir tersebut menciptakan akulturasi budaya yang dibawa antar-pelaku kegiatan perdagangan. Di bagian utara Jawa, akulturasi menumbuhkan karakter unik yang dapat dilihat pada tradisi budaya maupun pada elemen fisik kotanya. Salah satu daerah yang mengalami pengaruh kebudayaan dari luar dan menciptakan suatu akulturasi budaya adalah Juwana.

Juwana merupakan kota kecamatan yang berada di wilayah Kabupaten Pati. Juwana terletak di bagian timur laut Kabupaten Pati dan merupakan muara Sungai Juwana yang bernama Sungai Silugonggo. Penduduk Juwana mayoritas merupakan masyarakat suku Jawa dan terdapat penduduk keturunan Tionghoa dalam jumlah kecil/minoritas. Sejarah kedatangan etnis Cina di Juwana diindikasikan dengan adanya ekspedisi besar dari Tiongkok yang dipimpin oleh Laksamana Cheng Ho sekitar tahun 1405 hingga 1433 (Daradjadi, 2013). Rombongan tersebut menyinggahi kota-kota pelabuhan penting yang menjadi tujuan mereka, antara lain Jepara, Juwana, Tuban, Gresik, dan Pasuruan. Selanjutnya, sebagian dari mereka menetap di kota-kota yang disinggahi tersebut.

Juwana dilalui grote postweg atau jalan raya pos yang dibangun pada masa kolonial Belanda ketika diperintah oleh Gubernur Jenderal Herman Willem Daendels. Pada masa tersebut, Juwana adalah daerah berstatus keasisten-residenan, kemudian diturunkan menjadi kabupaten. Pada tanggal 1 Januari 1902, Juwana menjadi kawedanan (Toer, 2005). Pada masa tersebut, Juwana berada pada posisi setingkat di atas kecamatan dan di bawah kabupaten. Hingga saat ini, peninggalan kolonialis Belanda masih terlihat pada bangunan fasilitas publik dan beberapa rumah hunian di Juwana. Selain itu, terdapat juga bangunan-bangunan yang bergaya arsitektur Cina.

Bangunan bernilai sejarah banyak ditemukan di Desa Kauman. Desa ini berbatasan langsung dengan Sungai Juwana sehingga menjadi lokasi yang strategis bagi masyarakat maupun pedagang lokal dan asing. Sebagai akibatnya, kebudayaan Jawa, Islam, dan Tionghoa hidup berdampingan di permukiman Kauman. Desa Kauman terbagi menjadi dua kampung besar, yaitu Kampung Kauman dan Kampung Pecinan. Desa Kauman memiliki ciri kota kuno di Pulau Jawa yang ditandai dengan keberadaan Alun-alun Juwana. Berdasarkan pola ruang kota kuno di Jawa, alun-alun memiliki fungsi penting, yaitu sebagai pusat kegiatan dan landmark suatu kota (Ashadi, 2017). Di sekitar Alun-alun Juwana, berdiri bangunan bekas Kantor Kawedanan Juwana, Masjid Agung Juwana, dan Pasar Lama Juwana. Selain itu, kawasan tersebut juga dikelilingi oleh permukiman penduduk. Perkembangan teknologi transportasi darat berpengaruh terhadap pusatpusat pertumbuhan di sekitar maupun di luar kawasan pesisir. Hal ini menjadikan pertumbuhan dan perkembangan kota-kota di pesisir 
mengalami stagnasi, bahkan mengalami penurunan. Saat ini, kawasan pesisir identik dengan kekumuhan dan identitas yang kurang baik bagi suatu kota.

\section{Teori Morfologi Kota}

Menurut Trancik (1986), teori morfologi kota meliputi figure ground, linkage, dan place. Adapun deskripsi masing-masing unsur sebagai berikut:

1. figure ground, menekankan pada elemen solid dan void pada kota. Solid adalah bagian dari kota yang terbangun, sementara void adalah bagian dari kota yang tidak terbangun;

2. linkage, menekankan pada hubungan antar pusat aktivitas yang ada di dalam kota; dan

3. place, menekankan pada makna dari setiap ruang yang ada pada kota.

\section{Citra Kota dan Elemen Pembentuk Citra Kota}

Citra kota merupakan bayangan visualisasi dari suatu tempat atau ruang yang dibentuk dari irama tempat atau ruang tersebut mencerminkan suatu waktu (sense of time). Citra kota tumbuh mengakar dalam aktivitas sosial-ekonomi-budaya masyarakat kota (Lynch, 1960). Citra kota memberikan kemudahan bagi pengguna jalan untuk memperoleh orientasi dan pandangan yang nyaman dengan mengenali karakter suatu kawasan (Lazuardi, Astuti, \& Rini (2018). Wulanningrum (2014) mengemukakan bahwa terdapat tiga unsur yang memengaruhi kesan seseorang terhadap suatu kawasan, yaitu:

1. identitas sebagai potensi yang dibacakan, yaitu kemampuan orang dalam memahami gambaran suatu kawasan. Subjek mengidentifikasi kawasan melalui objek-objek, perbedaan antarobjek, serta perihal lain yang dapat diketahui;

2. struktur sebagai potensi yang disusun, yaitu kemampuan orang dalam melihat pola-pola kawasan melalui identifikasi hubungan antarobjek, hubungan subjek-objek, dan pola lain yang dapat dilihat; dan
3. makna sebagai potensi yang dibayangkan, yaitu kemampuan memahami ruang kota.

Elemen pembentuk citra kota menurut Lynch (1960) dalam buku The Image of the City menjelaskan pengetahuan mengenai elemenelemen pembentuk kota. Elemen-elemen tersebut menciptakan citra kota yang memberikan orientasi, identitas yang kuat, serta perasaaan nyaman terhadap suatu kota. Identitas kawasan akan berkesan dan mudah dikenali bukan hanya oleh penghuni kawasan, namun juga pengunjung yang berasal dari luar kawasan (Lazuardi, et al., 2018). Ada lima elemen kota berdasarkan teori Lynch (1960), yaitu:

1. path (jalur/jalan utama), merupakan elemen utama karena pengamat bergerak dan berpindah tempat melalui jalan. Elemen ini menjadi penghubung bagi elemen-elemen lain. Contoh elemen path adalah jalan utama keluar masuk kawasan, jalur pejalan kaki dengan rimbunan pohon, dan jalan di antara pertokoan Cina. Elemen path yang menjadi jalur ke titik penting seperti fasilitas publik atau simbol kota akan memunculkan karakter kuat dan lebih mudah diingat oleh pengamat;

2. edge (tepi/pinggiran/batas), merupakan elemen linier yang membatasi suatu kawasan. Elemen ini dapat berupa sungai, jalan, deretan pohon (green belt), rel kereta api, saluran irigasi, dan sejenisnya yang menjadi penegas batas dengan kawasan di sekitarnya. Elemen edge harus jelas menjadi pengakhiran atau permulaan sebuah kawasan;

3. district (penggolongan area dengan karakter atau fungsi tertentu), yaitu bagian kota yang memiliki ciri khas yang mirip bentuk, pola, wujud, dan fungsinya. Dalam suatu kota, dapat ditemukan district dengan fungsi permukiman (kawasan permukiman) di bagian dalam kawasan dan district dengan fungsi perdagangan (kawasan perdagangan) di bagian depan kawasan yang berbatasan dengan kawasan lain, terutama bagian yang menjorok ke jalan utama yang ramai. Contoh lainnya adalah Kampung Pecinan; 
4. nodes (simpul kawasan), yaitu titik pertemuan segala arah pada kawasan, dapat berupa taman kawasan, alun-alun, persimpangan jalan, dan sebagainya. Pada beberapa kawasan tertentu, terdapat titik kumpul masyarakat yang bisa digunakan sebagai titik evakuasi pada saat terjadi bencana. Elemen ini merupakan titik strategis yang biasanya menjadi pusat aktivitas.

5. landmark (tetenger), yaitu titik dengan objek fisik yang menjadi penanda suatu kawasan. Apabila landmark memiliki nilai/makna yang khas, maka pengamat akan segera menyadari telah memasuki suatu kawasan setelah melihatnya. Landmark mempunyai ciri visual yang menarik perhatian serta dapat ditemukan dalam bentuk tugu, menara, masjid, dan sebagainya.

\section{METODE PENELITIAN}

Penelitian dilaksanakan di Desa Kauman, Kecamatan Juwana, Kabupaten Pati pada Bulan Februari-Maret 2020. Metode penelitian yang digunakan adalah kualitatif dengan analisis deskriptif. Metode tersebut sesuai untuk mendeskripsikan dan menginterpretasikan keadaan Kawasan Kauman Juwana dengan bantuan data yang dikumpulkan. Data yang digunakan adalah data primer dan data sekunder. Data primer diperoleh melalui hasil pengamatan oleh penulis dan wawancara kepada lima narasumber yang dipilih menggunakan teknik purposive sampling. Narasumber yang dipilih memiliki krite- ria usia di atas 25 tahun dan lama tinggal di kawasan penelitian lebih dari 25 tahun. Kriteria usia di atas 25 tahun ditetapkan karena dianggap sudah dapat menentukan pilihan dengan konsisten dan mandiri. Kriteria lama tinggal ditetapkan dengan asumsi bahwa narasumber telah hafal dan paham tentang detail fisik dan suasana kawasan penelitian. Selanjutnya, data sekunder diperoleh melalui studi literatur.

Analisis data menggunakan teori morfologi kota menurut Trancik (1986), yang terdiri atas figure ground, linkage, dan place. Selain itu, penggambaran citra kota Kauman dilakukan dengan menganalisis lingkungan fisik berdasarkan elemen-elemen pembentuk citra kota menurut Lynch (1960), yaitu paths (jalan), edges (batas), districs (kawasan), nodes (simpul), dan landmark (tetenger). Elemenelemen fisik tersebut melekat pada ingatan yang membentuk citra terhadap kawasan oleh seseorang.

Cara yang dilakukan untuk memperoleh elemen-elemen pembentuk citra kawasan adalah wawancara dan peta mental. Peta mental merupakan cara untuk memberikan pemahaman suatu tempat berdasarkan ingatan dan menguraikan kembali informasi terkait lokasi dan tanda-tanda pada lingkungan geografis (Purwanto \& Wijayanti, 2015). Melalui peta mental, informasi terkait penelitian dapat diketahui dari memori narasumber pada objek, letak, dan gambaran kondisi di Kauman Juwana. Kerangka analisis penelitian dapat dilihat pada Gambar 1.

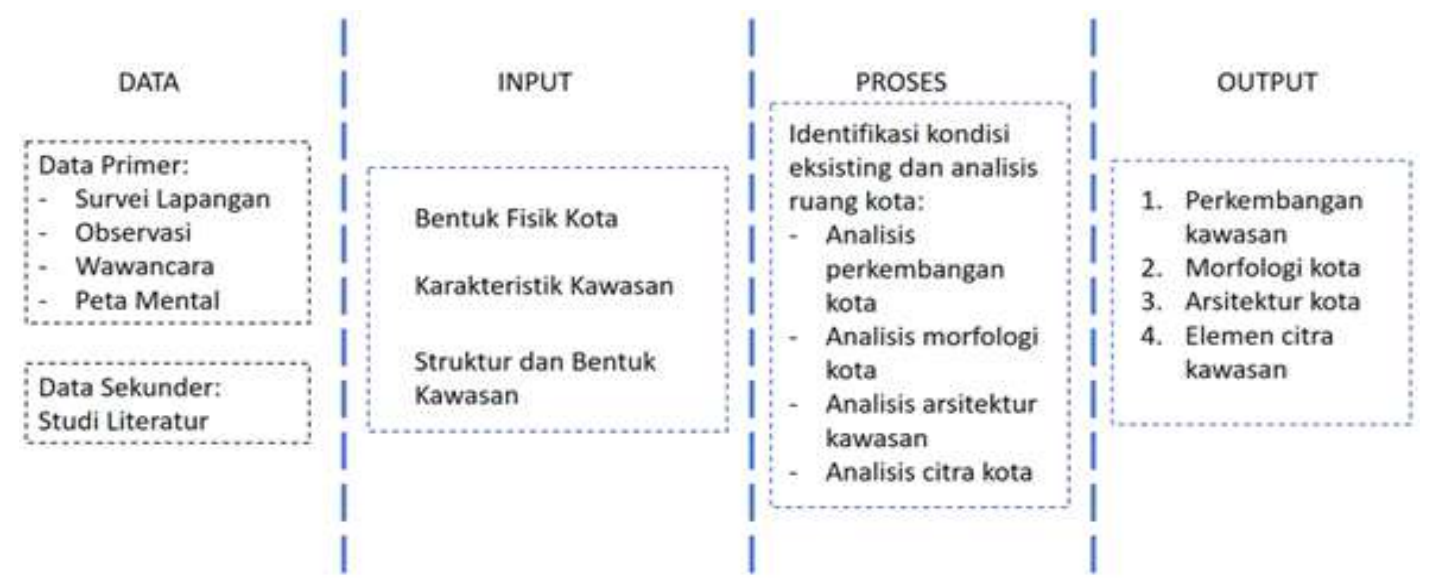

Gambar 1.

Kerangka Analisis Penelitian

Sumber: Hasil Analisis, 2020 


\section{HASIL DAN PEMBAHASAN}

\section{Perkembangan Perkotaan Juwana}

Juwana berkembang dari sektor maritim. Hal ini sesuai dengan sejarah perkembangan kota-kota di Indonesia yang banyak muncul dari wilayah pesisir (Kurniati, 2016). Berdasarkan Rencana Tata Ruang Wilayah (RTRW) Kabupaten Pati Tahun 2010-2030, Juwana merupakan kawasan perkotaan bersama dengan Kecamatan Jakenan, Kecamatan Kayen, Kecamatan Pati, dan Kecamatan Tayu (Jakatinata) (Suroso, 2019).

Berada di pesisir pantai utara Jawa Tengah, Juwana memiliki sejarah perkembangan yang erat kaitannya dengan aktivitas perdagangan oleh pedagang-pedagang asing. Pada abad ke16, Juwana merupakan salah satu kota pelabuhan penting di pesisir utara Jawa. Komoditas perdagangan di Juwana yaitu hasil bumi dan candu/opium. Selain itu, permukiman Pecinan di Juwana diawali dari peristiwa Geger Pecinan atau Perang Kuning yang terjadi sekitar tahun 1740 di Batavia. Peristiwa tersebut membuat sebagian etnis Tionghoa mengungsi ke kota-kota di pesisir utara Jawa, salah satunya melalui Sungai Juwana hingga mendarat dan menetap di Juwana (Daradjadi, 2013; Kurniati, 2016).

Dua abad yang lalu, Juwana merupakan bandar dagang yang ramai dan terkenal sebagai kawasan industri galangan kapal (Toer, 2005). Pada masa tersebut, Juwana berkembang pesat sebagai kota bandar dan kota dagang dengan banyak penduduk etnis Tionghoa. Selanjutnya, Sungai Juwana menjadi poros aktivitas masyarakat sehingga tidak mengherankan jika hingga saat ini, tepi Sungai Juwana merupakan permukiman yang padat.

Permukiman Juwana memiliki ciri tumbuh dari tepian Sungai Silugonggo dengan bentuk permukiman linier (Widayati, Ninawati, Jayanti, \& Surya, 2017). Tahun 1808, Daendels membangun jalan raya pos (grote postweg) dari Anyer hingga Panarukan. Sejak dibangun jalan raya pos tersebut, orientasi pembangunan permukiman beralih dari Sungai Silugonggo menuju ke arah jalan raya pos (Kurniati, 2016). Permukiman penduduk lambat laun menyebar hingga ke pedalaman dan berkembang membentuk pola radial dengan pusat Alun-alun Juwana sebagai ruang terbuka sekaligus pusat orientasi. Selanjutnya, perkotaan Juwana tumbuh dengan munculnya jalan-jalan yang membentuk permukiman dan kegiatan lainnya.

Hingga tahun 1960-an, Juwana banyak dihuni oleh masyarakat Tionghoa dengan permukiman Pecinan (Triartantio, 2017). Saat ini, permukiman lama dengan bangunan-bangunan lama hanya ditemukan di Jalan Silugonggo dan Kampung Kauman di belakang Masjid Agung Juwana. Mayoritas bangunan merupakan bangunan baru. Perkembangan perkotaan Juwana banyak didominasi oleh sektor perdagangan dan jasa, terutama dari sektor perikanan. Hingga saat ini, Juwana menjadi salah satu perkotaan besar di Kabupaten Pati.

Pola jaringan di perkotaan Juwana terpusat di Alun-alun Juwana yang terletak di Desa Kauman. Desa Kauman terletak di pusat Kecamatan Juwana. Orientasi Desa Kauman terhadap Kecamatan Juwana dapat dilihat pada Gambar 2.

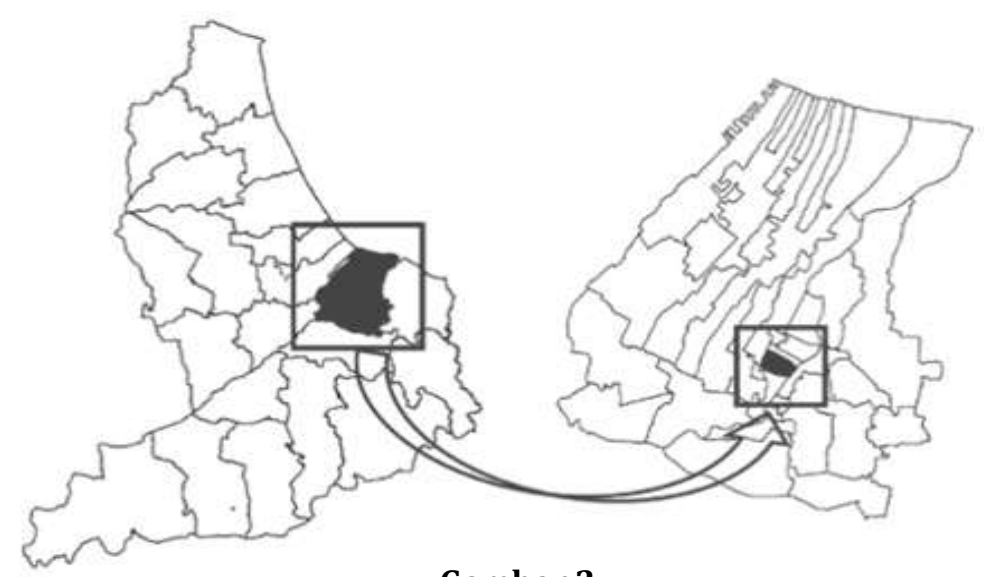

Gambar 2.

Orientasi Desa Kauman Terhadap Kecamatan Juwana Sumber: Hasil Analisis, 2020 


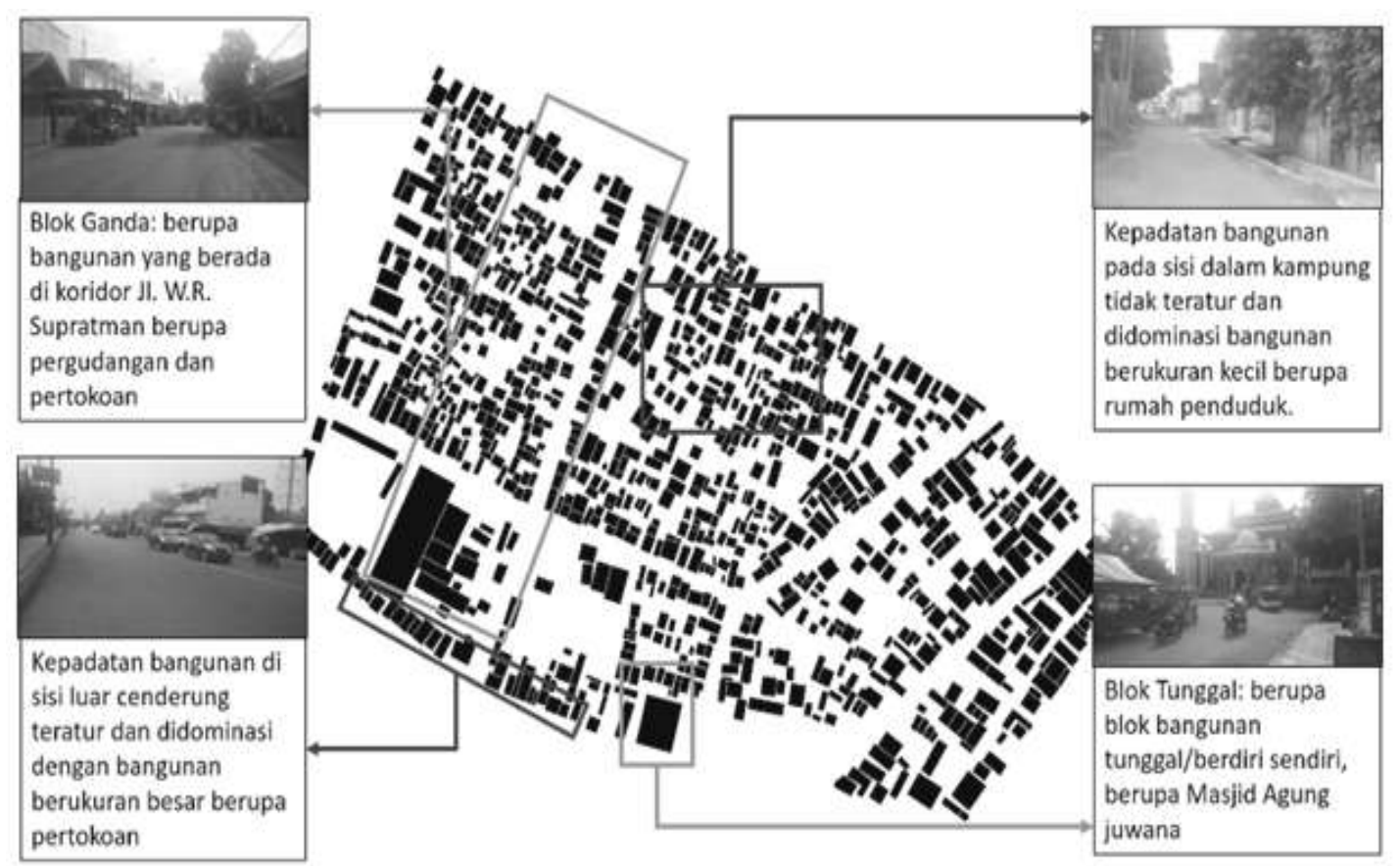

Gambar 3.

Elemen Solid di Kauman Juwana

Sumber: Hasil Analisis, 2020

\section{Morfologi Kawasan Kauman Juwana}

Untuk mengetahui morfologi kawasan di Kauman Juwana, analisis yang digunakan yaitu analisis figure ground, linkage dan place.

\section{Figure Ground}

Analisis figure ground melihat melalui tekstur kota yang dibedakan antara bagian yang terbangun (building mass) dan ruang tidak terbangun/ruang terbuka (open space). Media analisis yang digunakan adalah gambar peta hitam dan putih untuk mengidentifikasi elemen solid dan void pada kawasan Kauman. Solid digambarkan dengan warna hitam, sedangkan kawasan di luar kawasan terbangun ditunjukkan dengan warna putih.

\section{Solid}

Elemen solid pada kawasan menunjukkan kepadatan bangunan didominasi oleh bangunan yang cenderung tidak teratur dan berukuran kecil. Hal tersebut menunjukkan bahwa Desa Kauman Juwana didominasi oleh bangunan-bangunan dengan fungsi rumah penduduk dan toko milik penduduk. Sementara itu, bangunan yang berukuran besar di Kauman Juwana berupa Masjid Agung Juwana, bangunan pertokoan, serta pergudangan yang banyak tersebar di sepanjang Jalan Pantura. Berdasarkan analisis figure ground, terlihat bahwa bangunan yang terletak di Jalan W.R. Supratman, Jalan P. Diponegoro, dan Jalan Silugonggo memiliki bangunan yang teratur dan sejajar linier mengikuti jalan. Contoh elemen solid pada kawasan penelitian dapat dilihat pada Gambar 3 .

\section{Void}

Elemen void biasanya berupa kawasan terbuka, baik taman maupun ruang terbuka lainnya. Pada kawasan Kauman Juwana, void terlihat di tepi Jalan Pantura berupa Alunalun Juwana dan Terminal Lama Juwana. Dua lokasi ini menjadi sarana aktivitas bagi pengguna kawasan, baik untuk berkumpul, bersosialisasi, maupun kegiatan ekonomi. Lokasi yang diidentifikasi sebagai void di Kauman Juwana bersifat publik dan berada di tepi jalur-jalur sirkulasi yang dilalui oleh kendaraan umum dan kendaraan pribadi. Elemen void dalam skala kecil tersebar di permukiman penduduk, berupa halaman rumah atau taman pribadi milik masyarakat di kawasan tersebut. Elemen void di kawasan penelitian dapat dilihat pada Gambar 4. 


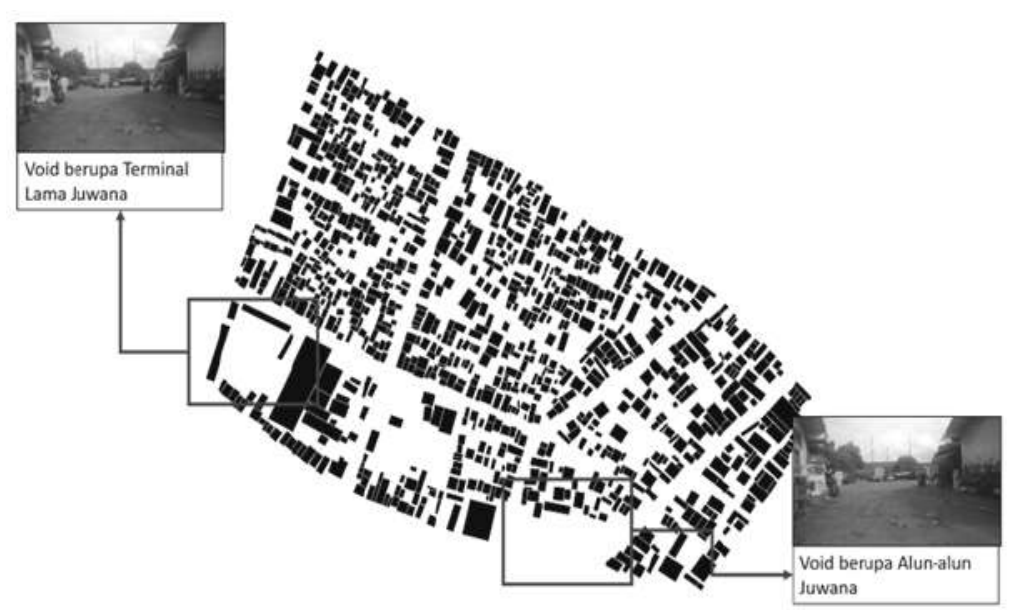

Gambar 4.

Elemen Void di Kauman Juwana Sumber: Hasil Analisis, 2020

\section{Linkage}

Elemen linkage terbagi menjadi 3 aspek, yaitu garis (line), koridor, dan sumbu (axis). Elemen garis di Kauman ditunjukkan oleh jaringan jalan yang tersebar di kawasan. Jaringan jalan ini merupakan sirkulasi penghuni kawasan yang juga adalah pengguna bangunan untuk melakukan aktivitas sehari-hari.

Elemen kedua ialah koridor yang membentuk ruang penghubung antara dua area. Elemen ini dapat ditemukan di Jalan W.R. Supratman yang menjadi penghubung Jalan Raya Pantura menuju pasar, area pergudangan ikan, dan pelabuhan yang berada di utara kawasan. Koridor W.R. Supratman didominasi oleh kawasan perdagangan dan jasa.

Elemen sumbu merupakan elemen yang menghubungkan antardaerah penting. Elemen ini terlihat di Jalan W.R. Supratman sebagai penghubung sekaligus jalur masuk menuju pusat perekonomian di Kecamatan Juwana. Jaringan jalan di Kauman dapat dilihat pada Gambar 5.

Place

Place merupakan identitas kawasan. Place penting untuk memahami karakteristik ruang fisik kawasan. Place diidentifikasi sebagai bangunan penting yang menjadi pusat aktivitas, yaitu Masjid Agung Juwana. Masjid ini tidak hanya menarik bagi penghuni kawasan, juga masyarakat dari luar kawasan. Masjid Agung Juwana selain menjadi pusat aktivitas keagamaan, juga menjadi simpul kegiatan, terutama perekonomian. Di sekitar Masjid Agung Juwana, banyak ditemukan orang berjualan. Place pada lokasi penelitian dapat dilihat pada Gambar 6.

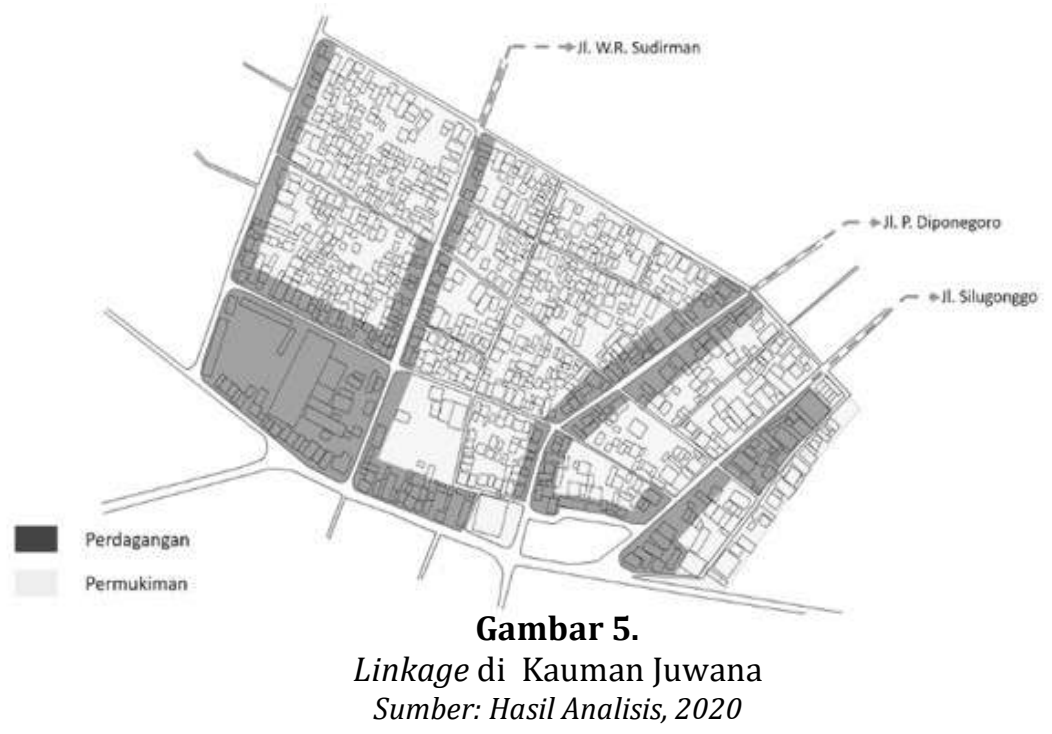




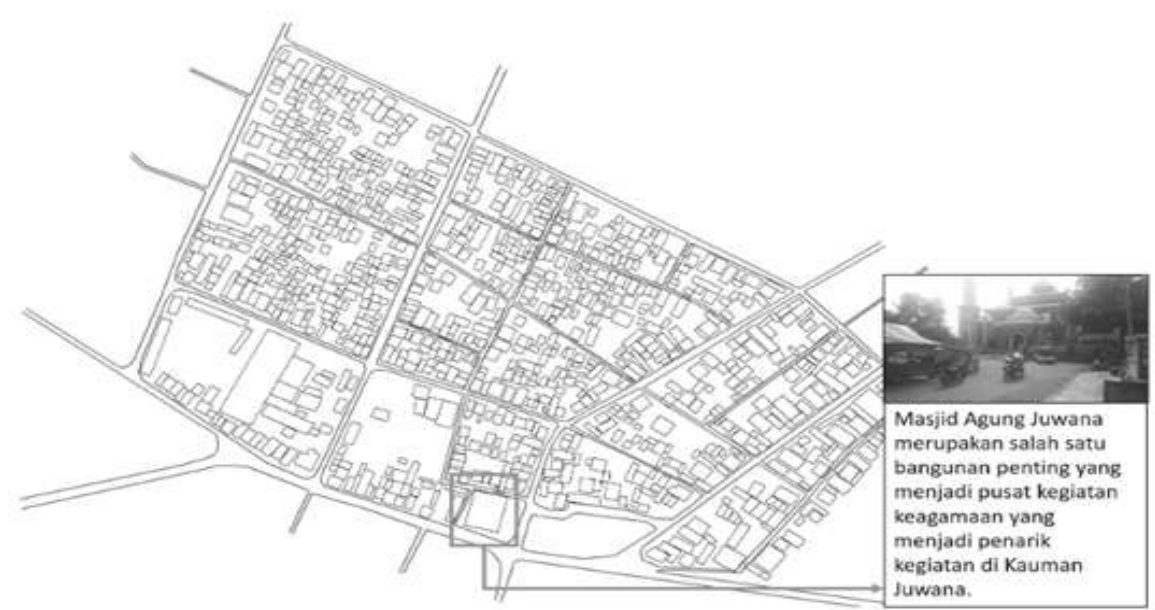

Gambar 6.

Place di Kauman Juwana Sumber: Hasil Analisis, 2020

\section{Arsitektur Kauman Juwana}

Kawasan Kauman Juwana memiliki ragam arsitektur yang beragam, diantaranya arsitektur Cina, kolonial, dan Jawa. Selain itu, juga terdapat langgam arsitektur modern.

\section{Bangunan Arsitektur Cina}

Bangunan dengan gaya arsitektur Cina bercirikan atap ekor burung walet dan dengan tepi atap seperti pelana kuda. Bangunan berlanggam Cina dapat ditemukan di tepi Sungai Juwana dan sepanjang koridor Jalan Silugonggo.

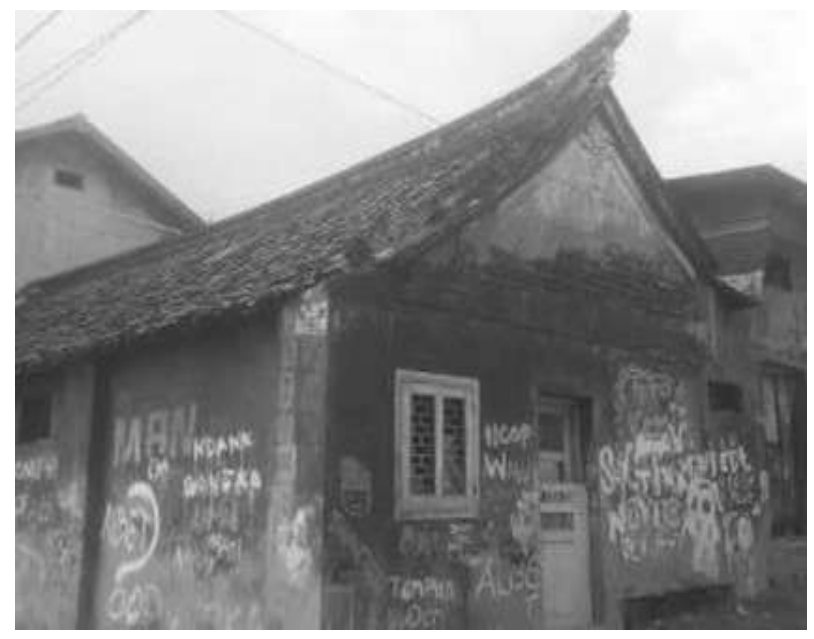

(7a) Atap Ekor Burung Walet
Contoh bangunan berarsitektur Cina dapat dilihat pada Gambar 7.

\section{Bangunan Arsitektur Kolonial}

Bangunan yang menggunakan arsitektur kolonial dapat ditemukan di beberapa titik di sekitar Alun-alun Juwana dan Jalan Silugonggo. Bangunan-bangunan peninggalan Belanda tersebut banyak berfungsi sebagai fasilitas publik, seperti SDN 1 Kauman dan Kantor Polsek Juwana. Contoh bangunan berarsitektur kolonial dapat dilihat pada Gambar 8.

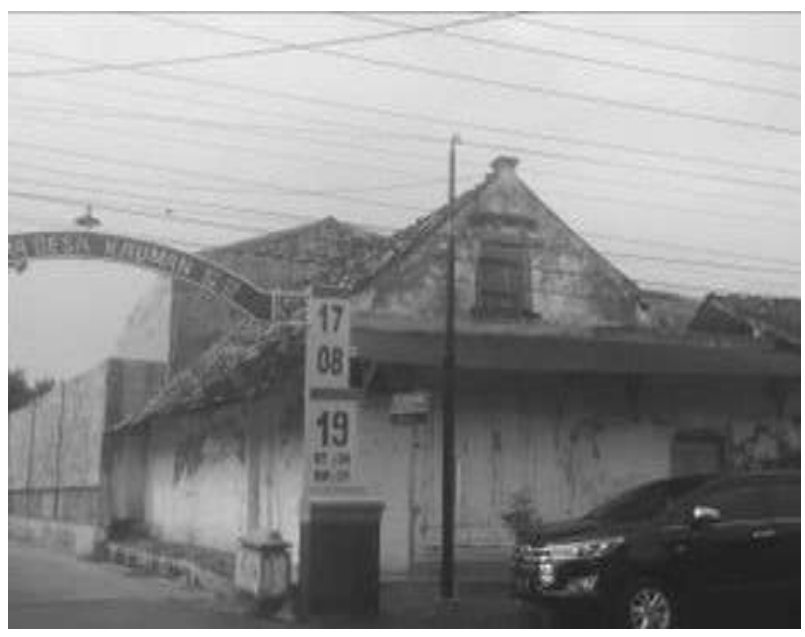

(7b) Atap Pelana Kuda

Gambar 7.

Bangunan Berarsitektur Cina Sumber: Hasil Analisis, 2020 


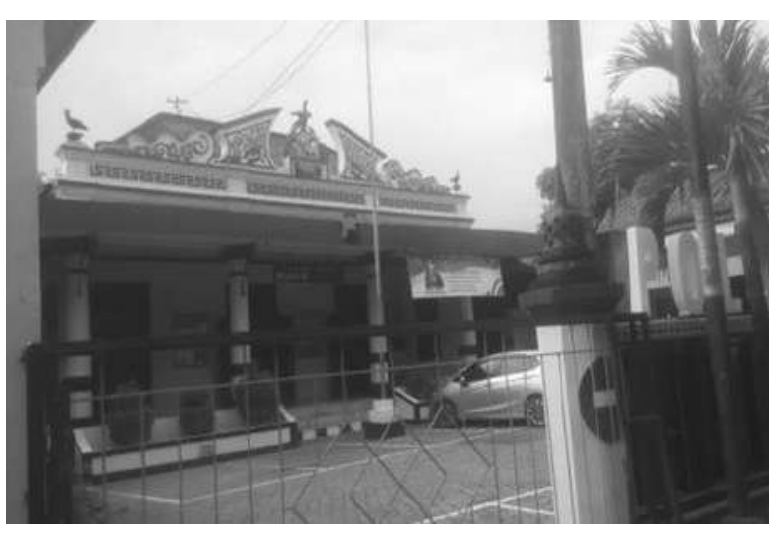

Gambar 8.

Mapolsek Juwana yang Berarsitektur Kolonial

\section{Bangunan arsitektur Jawa}

Bangunan dengan arsitektur Jawa banyak tersebar di seluruh kawasan. Namun demikian, bangunan berarsitektur Jawa pada umumnya terkonsentrasi di Kampung Kauman yang terletak di sekitar Masjid Agung Juwana. Contoh bangunan berarsitektur Jawa dapat dilihat pada Gambar 9.

\section{Elemen Citra Kawasan Kauman Juwana}

Hasil penelitian menunjukkan bahwa terdapat lima elemen pembentuk citra kota di Desa Kauman, Kecamatan Juwana yaitu:

Path

Path merupakan jalur atau sirkulasi yang biasanya digunakan masyarakat untuk melakukan pergerakan atau aktivitas. Elemen ini mudah dikenali karena manusia dapat merasakan dan mengamati kota dengan melakukan pergerakan melaluinya. Elemen path yang teridentif ikasi sebagai jalur yang biasanya digunakan di Desa Kauman Juwana adalah jalan utama yang bernama Jalan Silugonggo dan Jalan W.R. Supratman. Path tersebut merupakan jalan utama yang melalui kawasan Kauman Juwana.

Jalan Silugonggo menjadi akses utama masyarakat, baik dari Desa Kauman maupun dari luar kawasan menuju dan/atau melalui kawasan Kauman. Akses ini menghubungkan jalan Pantura dengan Pelabuhan Juwana yang terletak di utara kawasan. Adapun Jalan W.R. Supratman merupakan penghubung antara

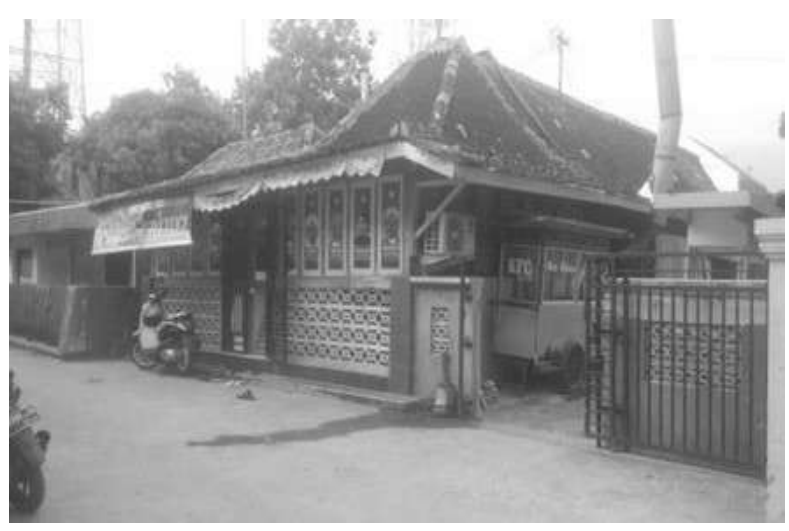

Gambar 9.

Bangunan Arsitektur Jawa di Kampung Kauman

jalan Pantura dengan kawasan pergudangan ikan di sebelah utara kawasan. Path pada Kawasan Kauman dapat dilihat pada Gambar 10 dan Gambar 11.

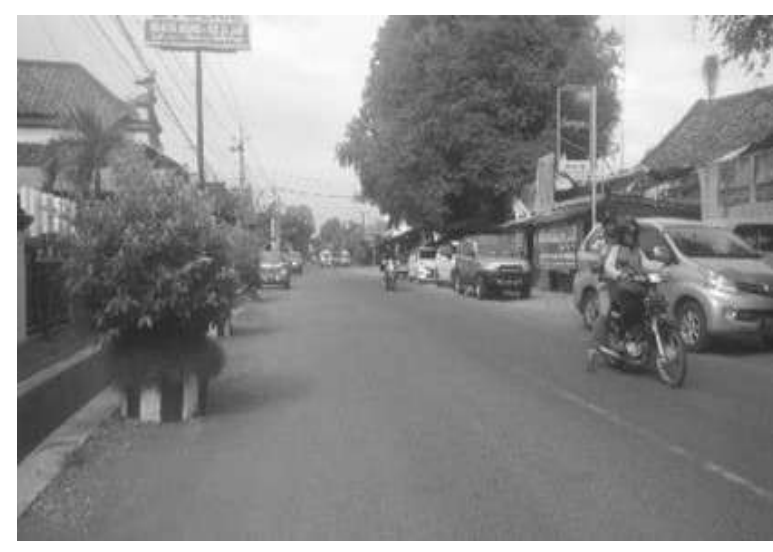

Gambar 10.a

Jalan Silugonggo

Sumber: Hasil Analisis, 2020

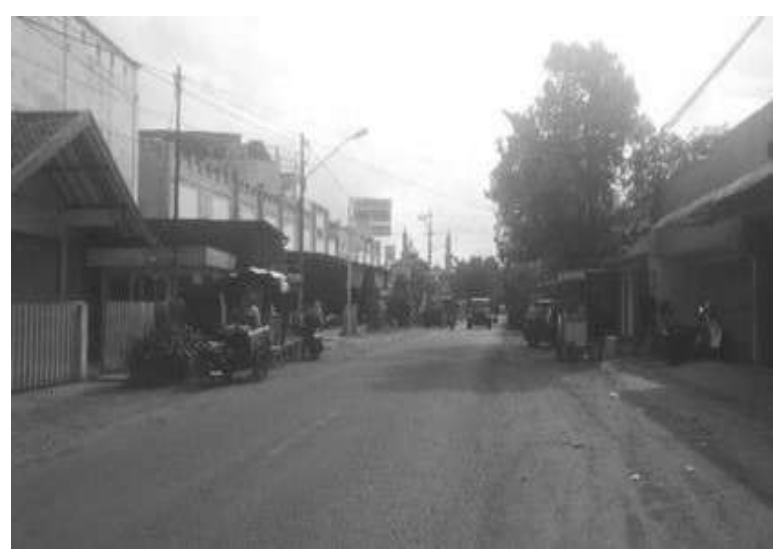

Gambar 10.b

Jalan W.R. Supratman

Sumber: Hasil Analisis, 2020 


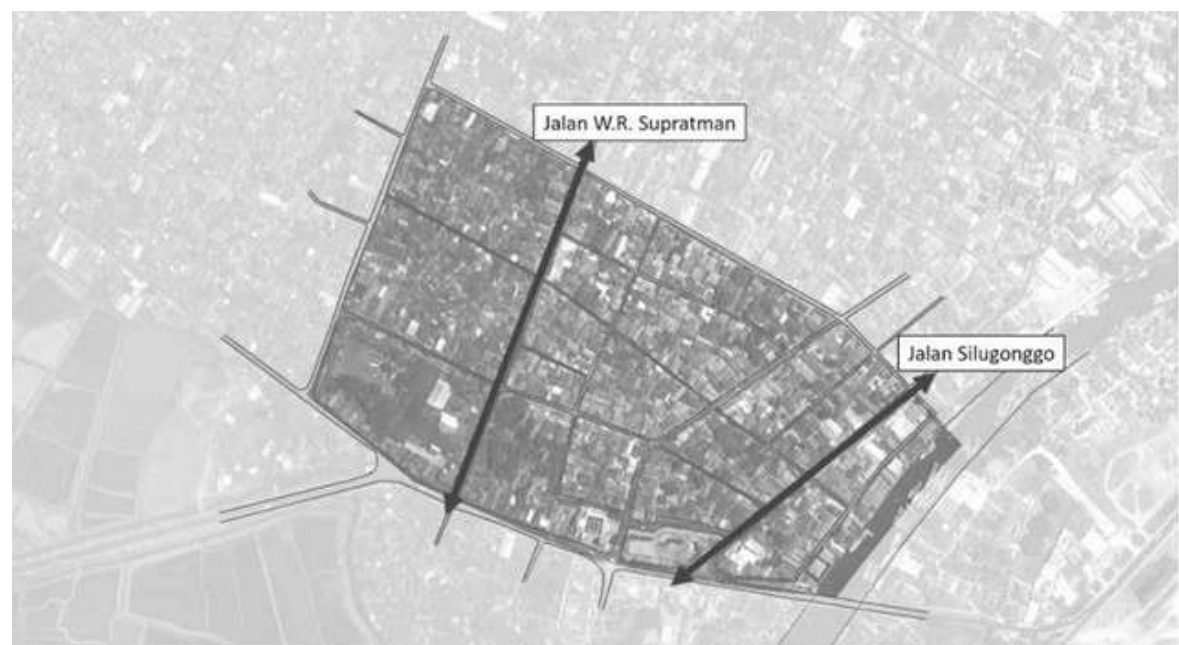

Gambar 11.

Elemen Path di Kauman Juwana Sumber: Hasil Analisis, 2020

Koridor Jalan Silugonggo didominasi oleh bangunan dengan fungsi perdagangan dengan penampakan fasad pertokoan lama yang sebagian sudah berhenti beroperasi. Selain itu, sepanjang koridor juga ditemukan fasilitas publik, seperti kantor polisi dan gereja. Sementara itu, koridor Jalan W.R. Supratman didominasi oleh bangunan baru dengan fungsi bangunan sebagai hunian/tempat tinggal dan tempat usaha. Jalur ini banyak dilalui oleh kendaraan besar yang melakukan kegiatan bongkar muat maupun distribusi produk perikanan yang terletak di bagian utara kawasan.
Edge

Edge merupakan elemen citra yang memisahkan suatu kawasan dengan kawasan sekitarnya. Elemen ini dapat berupa sungai, jalan, deretan pohon, jalur kereta api, saluran irigasi, dan sejenisnya yang menjadi pembatas kawasan. Elemen edge juga dapat disebut sebagai tepian kawasan. Di Kauman, elemen edge teridentifikasi berupa sungai dan jalan. Sisi utara kawasan dibatasi oleh Jalan Pajeksan, sedangkan sisi barat dibatasi oleh Jalan Komodo. Sungai Juwana membatasi kawasan di sisi timur, dan jalan pantura membatasi kawasan pada sisi selatan. Elemen edge dapat dilihat pada Gambar 12.

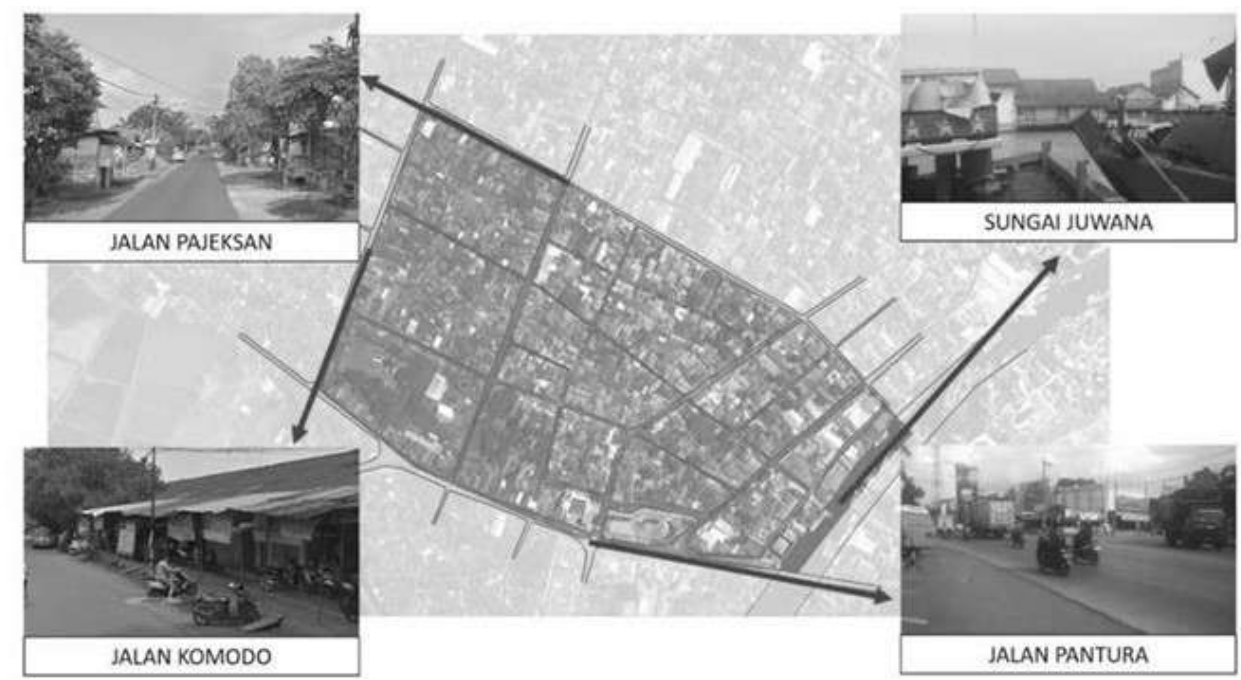

Gambar 12.

Elemen Edges di Kauman Juwana

Sumber: Hasil Analisis, 2020 


\section{District}

District merupakan suatu bagian kota dengan karakter khusus yang dapat dikenali oleh pengamat melalui bentuk, pola, wujud, fungsi, dan batas yang jelas. Karakter ini dapat dirasakan ketika berada di dalam kawasan maupun ketika mengamati dari luar kawasan dengan membandingkan dengan daerah sekitar wilayah pengamatan. Kauman memiliki tiga area dengan kesamaan karakter (district), yaitu Kampung Kauman (area sekitar Masjid Agung Juwana), Kampung Pecinan (area sekitar Kelenteng Tjoe Tik Bio, dan koridor yang ada di Jalan Silugonggo; Jalan P. Diponegoro; dan Jalan W.R. Supratman (area perdagangan dan penyediaan jasa). Lokasi district dapat dilihat pada Gambar 4.

Kauman merupakan kawasan padat bangunan dengan beragam karakter fisik bangunan yang tersebar. Pendefinisian elemen ketiga ini agak sulit dilakukan melalui kesamaan karakter fisik atau penampakan muka bangunan pada kawasan. Hasil pengamatan menunjukkan hanya terdapat sedikit kesamaan pada beberapa bangunan yang membentuk kelompok cukup kecil dan berada dalam wilayah yang sempit. Hal ini kemungkinan merupakan hasil perubahan yang sudah terjadi sebelumnya, dimana pada periode dahulu, bangunan di kawasan ini cukup seragam (homogen). Kesamaan karakter dapat dijumpai pada area di sekitar Masjid Agung Juwana dan Kelenteng Tjoe Tik Bio.
Karakter di sekitar Masjid Agung Juwana yaitu bangunan berlanggam Jawa dengan karakter pemukim yang merupakan masyarakat Jawa dan beragama Islam. Area tersebut lebih dikenal sebagai Kampung Kauman. Sementara itu, karakter di sekitar Kelenteng Tjoe Tik Bio menunjukkan cukup banyak bangunan yang menampakkan corak langgam bangunan Cina. Area tersebut lebih dikenal dengan Kampung Pecinan dan didominasi oleh pemukim beretnis Tionghoa. Melalui identifikasi fungsi bangunan, kawasan Kauman secara umum merupakan permukiman dengan detil fungsi bangunan sebagai hunian/tempat tinggal dan fungsi tambahan bangunan berupa warung/ toko kelontong. Penambahan fungsi bangunan sebagai tempat usaha terjadi di sepanjang koridor jalan utama, yaitu Jalan Silugonggo dan Jalan P. Diponegoro, yang menjadi akses vital masyarakat. Oleh karena itu, terdapat kecenderungan membentuk kawasan pertokoan dan penyediaan jasa. Elemen district dapat dilihat pada Gambar 13.

\section{Nodes}

Nodes merupakan titik pertemuan segala arah pada kawasan, berupa taman kawasan, alun-alun, persimpangan jalan, dan sebagainya. Pada beberapa kawasan tertentu, terdapat titik kumpul masyarakat yang dapat digunakan sebagai titik evakuasi saat terjadi bencana. Nodes atau titik simpul kawasan Kauman adalah Alunalun Juwana. Alun-alun Juwana selain menjadi simbol ruang terbuka hijau, juga mewadahi

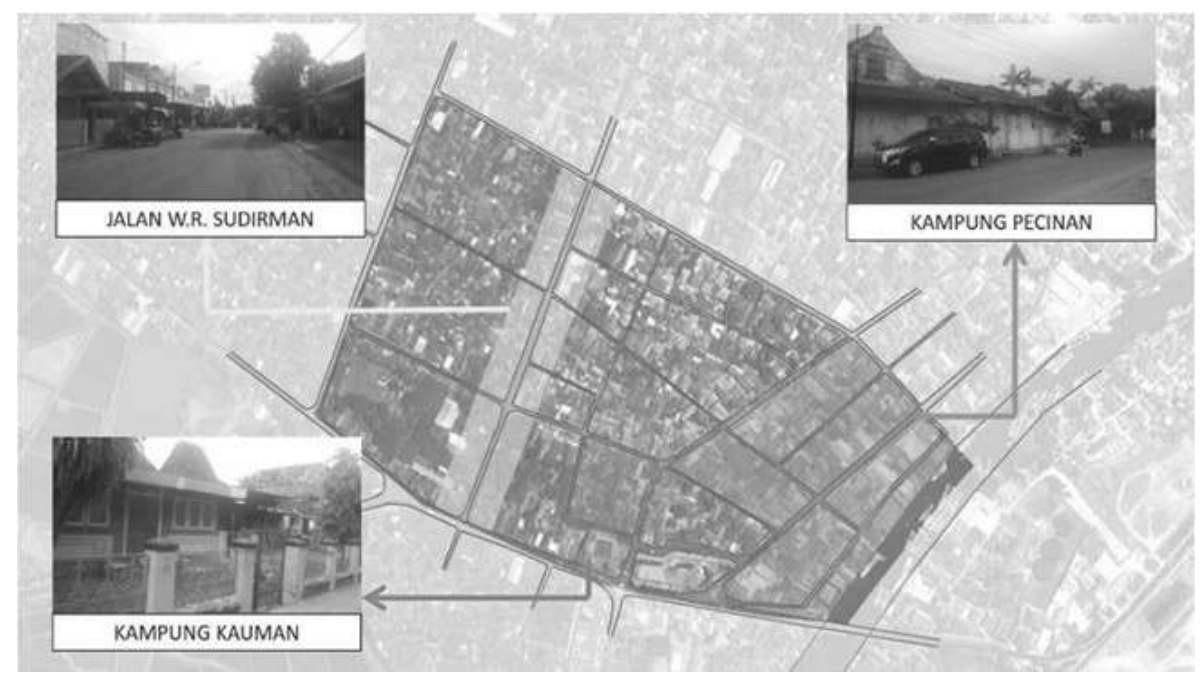

Gambar 13.

Elemen District di Kauman Juwana Sumber: Hasil Analisis, 2020 


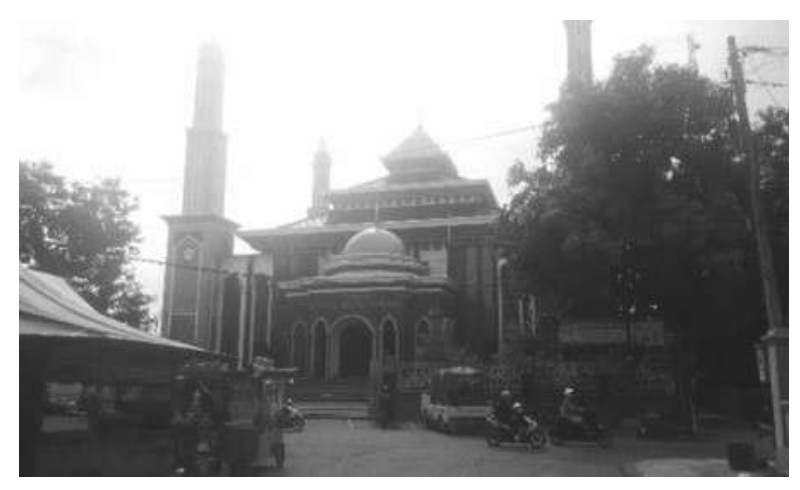

Gambar 14.

Nodes Area PKL

Alun-alun di Depan Masjid Agung Juwana Sumber: Hasil Analisis, 2020

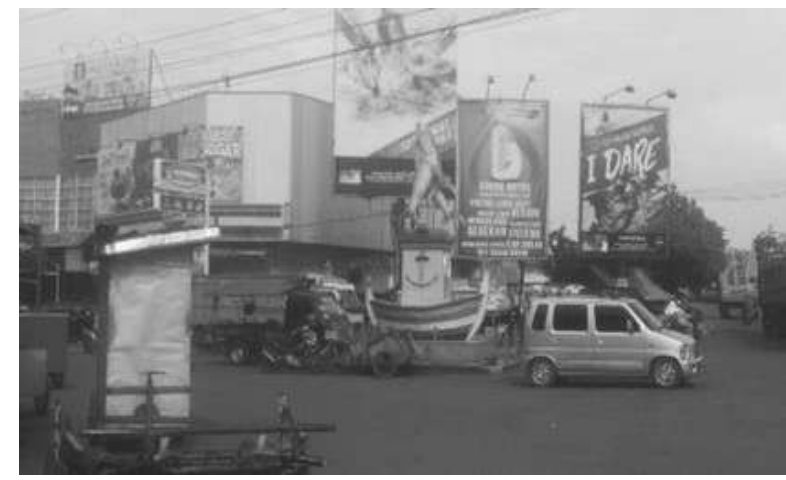

Gambar 15.

Nodes Pertokoan Modern di Sisi Timur Alun-alun Sumber: Hasi Analisis, 2020

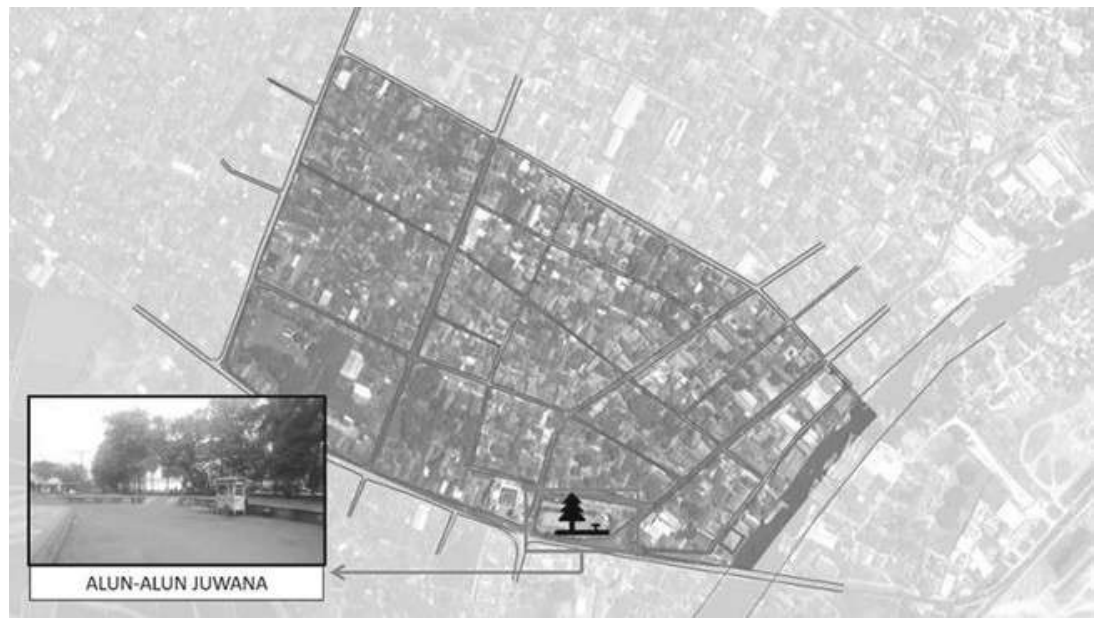

Gambar 16.

Elemen Nodes di Kauman Juwana

Sumber: Hasil Analisis, 2020

aktivitas perdagangan serta menjadi lokasi penyelenggaraan kegiatan publik seperti acara keagamaan dan acara sosial. Alun-alun Juwana memiliki lokasi strategis karena terletak di sisi jalan Nasional yang menjadi jalur kegiatan dengan mobilitas tinggi. Alun-alun Juwana menjadi titik simpul kegiatan dari dalam dan luar kawasan Kauman Juwana. Selain tumbuhnya pertokoan di sekitar Alun-alun Juwana, terdapat pula kegiatan perdagangan yang biasanya terjadi pada sore hari dengan persebaran mengitari alun-alun. Oleh karena itu, Alunalun Juwana dapat dinyatakan sebagai simpul pergerakan kawasan. Elemen nodes dapat dilihat pada Gambar 14, 15, dan 16.

\section{Landmark}

Landmark merupakan titik dengan objek fisik yang menjadi penanda suatu kawasan. Apabila landmark memiliki nilai/makna yang khas, maka pengamat akan segera menyadari telah memasuki suatu kawasan setelah melihatnya. Landmark dapat ditemukan dalam bentuk tugu, menara, masjid, atau perbukitan. Landmark atau tetenger yang sering menjadi penanda bagi masyarakat kawasan Kauman dan sekitarnya adalah Alun-alun Juwana dan Masjid Agung Juwana. Kedua lokasi tersebut terletak berdekatan. Masjid Agung Juwana terletak di sebelah barat Alun-alun Juwana. Selain itu, landmark di kawasan tersebut juga berupa Kelenteng Tjoe Tik Bio yang berada di antara Sungai Juwana dan Jalan Silugonggo. Dengan melihat keberadaan Alun-alun Juwana dan Masjid Agung Juwana, dapat dipastikan bahwa seseorang sudah melewati kawasan Kauman. Sementara itu, apabila telah melewati Kelenteng Tjoe Tik Bio, artinya seseorang telah berada di dalam kawasan Kauman. Landmark di Kauman Juwana dapat dilihat pada Gambar 17. 


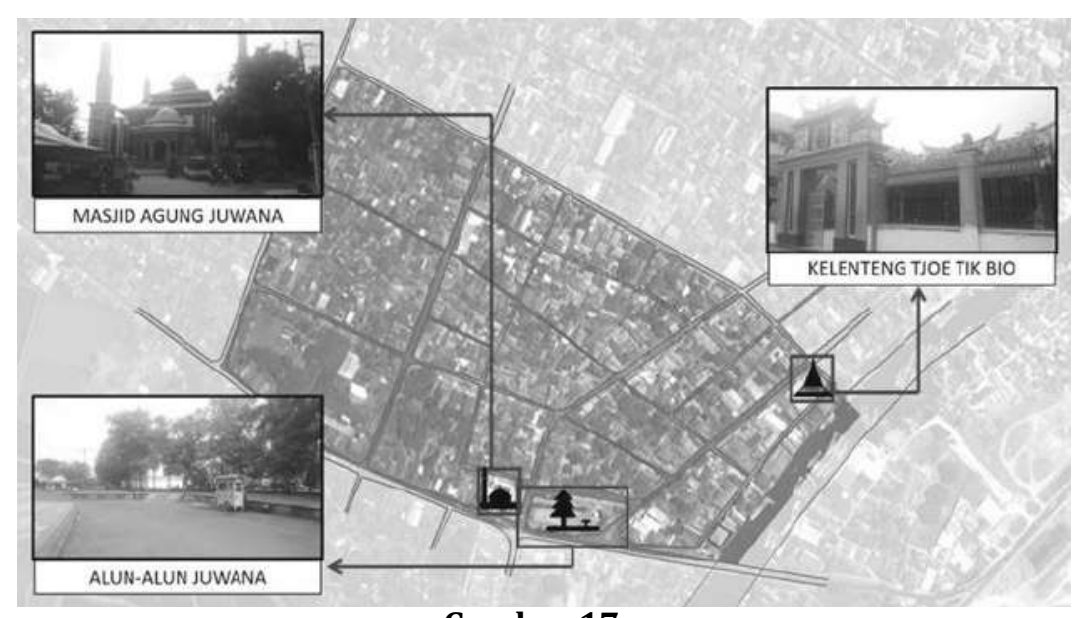

Gambar 17.

Elemen Landmark di Kauman Juwana

Sumber: Hasil Analisis, 2020

\section{KESIMPULAN DAN SARAN}

\section{Kesimpulan}

Hasil identifikasi dan analisis elemenelemen pembentuk citra kota Kauman Juwana merupakan gambaran kesan yang terhimpun dari pengamatan terhadap fisik kawasan Kauman oleh penulis dan narasumber yang merupakan penduduk yang mendiami Kauman. Berdasarkan morfologi kota, diperoleh hasil bahwa pada figure ground ditemukan, terdapat elemen solid blok tunggal berupa Masjid Agung Juwana serta elemen void berupa ruang terbuka hijau, yaitu Alun-alun Juwana dan Terminal Lama Juwana; linkage di kawasan ditemukan Jalan W.R. Supratman, Jalan Silugonggo, dan Jalan P. Diponegoro sebagai jalur sirkulasi penghuni kawasan dan masyarakat luar untuk beraktivitas; dan place berupa Masjid Agung Juwana yang menjadi pusat aktivitas sosial.

Berdasarkan lima elemen pembentuk citra kota, diperoleh hasil: elemen path (jalan/ jalur) meliputi Jalan Silugonggo dan Jalan W.R. Supratman; elemen edge (batas) meliputi Jalan Komodo, Jalan Pajeksan, Jalan Raya Pantura, dan Sungai Silugonggo atau Sungai Juwana; elemen district (kawasan berkarakter) meliputi Kampung Pecinan, Kampung Kauman, serta Koridor Jalan W.R. Supratman sebagai kawasan perdagangan; dan elemen nodes (simpul) adalah Alun-alun Juwana dan elemen landmark (tetenger) yaitu Masjid Agung Juwana, Kelenteng Tjoe Tik Bio dan Alun-Alun Juwana. Identitas Kauman Juwana sebagai permukiman lama yang dahulu bertumpu pada aktivitas perdagangan di aliran Sungai Juwana, kini berubah karena aktivitas perdagangannya berada pada jalur darat mengikuti koridor jalan W.R. Supratman dan Jalan Raya Pantura. Berbagai pengaruh perkembangan kota seperti kemajuan teknologi transportasi dan rencana pembangunan Kabupaten Pati mengakibatkan perubahan orientasi lokasi perdagangan. Selain itu, perkembangan tersebut juga berdampak terhadap aktivitas sosial-budaya dan perkembangan fisik terbangun di dalam kawasan Kauman. Hal tersebut dapat dilihat dari perubahan fungsi bangunan di sepanjang jalan raya sebagai rumah tinggal sekaligus fungsi ekonomi. Penampakan bangunan berkarakter kuat yang mewakili suatu langgam atau gaya bangunan tertentu masih tersisa di beberapa bangunan, antara lain bangunan bergaya Kolonial, Tradisional Jawa, dan Cina.

\section{Saran}

Beberapa saran yang dapat diberikan berdasarkan hasil kajian terhadap wilayah studi adalah (1) penelitian ini merupakan studi awal dalam mengkaji morfologi Kota Kauman dan dapat diteruskan dengan penelitian lanjutan untuk melihat perkembangan pola dan struktur kawasannya; (2) Kauman memiliki beberapa bangunan dengan potensi nilai historis yang mewakili suatu masa perkembangan kawasan. Oleh karena itu, penelitian lanjutan dibutuhkan untuk menilai potensi tersebut agar dapat ditetapkan upaya tepat dalam rangka 
pelestarian cagar budaya sesuai amanat Undang-Undang; (3) perlu adanya upaya Pemerintah Kabupaten Pati untuk mengarahkan dan mengendalikan pertumbuhan kawasan perdagangan di Desa Kauman, Kecamatan Juwana untuk menghindari pertumbuhan fisik terbangun yang tidak diinginkan pada kawasan Kauman; (4) pemerintah daerah perlu membantu mengembangkan potensi di Desa Kauman, seperti potensi pariwisata sejarah; (5) masyarakat diharapkan memperhatikan dan mematuhi regulasi terkait dengan pembangunan kawasan untuk mendukung pelestarian sejarah.

\section{DAFTAR PUSTAKA}

Ashadi. (2017). Alun-Alun Kota Jawa. Jakarta: Arsitektur UMJ Press.

Daradjadi. (2013). Geger Pacinan 1740-1743 Persekutuan Tionghoa-Jawa Melawan VOC. Jakarta: Penerbit Buku Kompas.

Kurniati, R. (2016). Sejarah Perkembangan Struktur Ruang Kota Lasem. Ruang, 2(3), 172-188. Diperoleh di http:// dx.doi.org/10.14710/ruang.1.4.172-188.

Lake, R.C., Mberu, Y.B., \& Diaz, A. (2019). Elemen-Elemen Pembentuk Sistem Kota Lama Kupang. Jurnal Arsitektur Komposisi, 12(3), 257-269.

Lazuardi, M. J., Astuti, W., \& Rini, E. F. (2018). Analisis Citra Kawasan Mangkunegaran Berdasarkan Penilaian Stakeholder dengan Konsep Legibility. Region, 13(1), 95-114.

Lynch, K. (1960). The Image of the City. Massachucetts: The M.I.T. Press.

Purwanto, E., \& Wijayanti. (2015). Gambaran Bentuk Spasial Kampus Undip Tembalang Menurut Kemampuan Peta Mental Mahasiswa. Jurnal Modul, 15(1), 23-38.
Suroso. (2019). Eksistensi Pembangunan Masyarakat dan Desa di Kawasan Perkotaan Kabupaten Pati. Jurnal Litbang, 15(2), 77-90.

Tallo, A.J., Pratiwi, Y., \& Astutik, I. (2014). Identifikasi Pola Morfologi Kota (Studi Kasus: Sebagian Kecamatan Klojen, di Kota Malang. Jurnal Perencanaan Wilayah dan Kota, 25(3), 213-227.

Toer, P.A. (2005). Jalan Raya Pos, Jalan Daendels. Jakarta: Lentera Dipantara.

Trancik, Roger. (1986). Finding Lost Space: Theories of Urban Design. New York: Van Nostrand Reinhold Company.

Triartantio, A. (2017). Perubahan Morfologi Permukiman Pecinan (Studi Kasus: Kauman Juwana Kabupaten Pati). (Skripsi). Diambil dari http://repository. unissula.ac.id.

Widayati, N., Ninawati, Jayanti, T.B., Surya, R. (2017) Early Studies on Potencies of Subdistrict Administration of Juwana, District Pati, Central Java. Prosiding Seminar ICET 2017. Jakarta: Universitas Tarumanegara.

Wulanningrum, S. D. (2016). Kajian Morfologi Kota (Studi Kasus: Kota Lama Semarang). Jurnal Ilmiah Arjouna, 1(1), 14-17.

\section{BIODATA PENULIS}

Wildansyah Firdaus Adiguna, lahir tanggal 27 Desember 1995 di Kabupaten Wonogiri. Pendidikan S1 Perencanaan Wilayah dan Kota Fakultas Teknik Universitas Diponegoro. Bekerja di Dinas Pekerjaan Umum dan Penataan Ruang Kabupaten Pati, Provinsi Jawa Tengah.

Marisa Triyanti, lahir pada tanggal 30 Maret 1994 di Kabupaten Ogan Komering Ilir, Sumatera Selatan. Pendidikan S1 Perencanaan Wilayah dan Kota Fakultas Teknik Universitas Diponegoro. Bekerja di Kantor Pertanahan Kota Pagar Alam, Provinsi Sumatera Selatan. 
